\title{
Absorption and distribution of etoricoxib in plasma, CSF, and wound tissue in patients following hip surgery—a pilot study
}

\author{
Bertold Renner • Josef Zacher • \\ Asokumar Buvanendran • Gerrit Walter • \\ Jochen Strauss • Kay Brune
}

Received: 1 July 2009 / Accepted: 30 November 2009 /Published online: 6 January 2010

(C) The Author(s) 2009. This article is published with open access at Springerlink.com

\begin{abstract}
The perioperative administration of selective cyclooxygenase-2 (COX-2)-inhibitors to avoid postoperative pain is an attractive option: they show favorable gastrointestinal tolerability, lack inhibition of blood coagulation, and carry a low risk of asthmatic attacks. The purpose of this study was to determine the cerebrospinal fluid (CSF), plasma, and tissue pharmacokinetics of orally administered etoricoxib and to compare it with effect data, i.e., COX-2inhibition in patients after hip surgery. The study was performed in a blinded, randomized, parallel group design. A total of 12 adult patients were included who received $120 \mathrm{mg}$ etoricoxib $(n=8)$ or placebo $(n=4)$ on day 1 postsurgery. Samples from plasma, CSF, and tissue exudates were collected over a period of $24 \mathrm{~h}$ post-dosing and analyzed for etoricoxib and prostaglandin $\mathrm{E}_{2}\left(\mathrm{PGE}_{2}\right)$ using liquid chromatography-tandem mass spectrometry and immuno-assay techniques. CSF area under the curve (AUC) $\left[\mathrm{AUCs}_{(\mathrm{O}-24 \mathrm{~h})}\right]$ for etoricoxib amounted to about
\end{abstract}

B. Renner $(\bowtie) \cdot K$. Brune

Institute of Experimental and Clinical Pharmacology and Toxicology,

University of Erlangen-Nuremberg,

Krankenhausstr. 9,

91054 Erlangen, Germany

e-mail: renner@pharmakologie.uni-erlangen.de

J. Zacher $\cdot$ G. Walter

Department of Orthopedics, Helios Klinikum Berlin-Buch,

Berlin, Germany

\author{
A. Buvanendran \\ Department of Anesthesiology, Rush University Medical Center, \\ Chicago, IL, USA \\ J. Strauss \\ Department of Anesthesiology, Helios Klinikum Berlin-Buch, \\ Berlin, Germany
}

$5 \%$ of the total AUC in plasma (range: 2-7\%). Individual CSF lag times with respect to $(50 \%)$ peak plasma concentration were $\leq 2 \mathrm{~h}$ in all but one case (median: $1 \mathrm{~h}$ ). $\mathrm{PGE}_{2}$ production in tissue was significantly blocked by the COX-2 inhibitor starting with the appearance of etoricoxib in tissue and lasting for the whole observation period of $24 \mathrm{~h}(P<0.01)$. In conclusion, etoricoxib reaches the CSF and site of surgery at effective concentrations and reduces $\mathrm{PGE}_{2}$ production at the presumed site of action.

Keywords Etoricoxib - Cerebrospinal fluid . Prostaglandin E C Cyclooxygenase 2 inhibitors . Pharmacokinetics

\section{Introduction}

Surgical trauma induces cyclooxygenase-2 (COX-2) upregulation and subsequent synthesis of prostaglandins locally (Lipsky et al. 1998) and in the central nervous system (CNS; Dolan et al. 2003). This leads to peripheral and central hyperalgesia (Woolf and Chong 1993; Reinold et al. 2005). Selective COX-2 inhibitors appear to block both peripheral and central hyperalgesia, but have little or no effect on platelet aggregation and asthma. These characteristics make them attractive candidates for perioperative use (Viola et al. 2007; Schwartz et al. 2008). Etoricoxib (a new selective COX-2 inhibitor available in many countries) has been reported to reduce postoperative pain after orthopedic surgery (Toivonen et al. 2007; Turan et al. 2008). When administered postoperatively to patients who had undergone hip replacement, etoricoxib provided analgesia similar to controlled release naproxen and superior to placebo (Rasmussen et al. 2005).

Prostaglandin $\mathrm{E}_{2}\left(\mathrm{PGE}_{2}\right)$ is the predominant eicosanoid released in damaged tissue (Samad et al. 2002). Animal 
data demonstrate an increase in spinal $\mathrm{PGE}_{2}$ after peripheral injury (Dirig and Yaksh 1999). Spinal administration of a COX-2 inhibitor in an animal inflammatory model decreased peripheral inflammation-induced central $\mathrm{PGE}_{2}$ concentrations and mechanical hyperalgesia (Woolf and Chong 1993; Samad et al. 2001; Reinold et al. 2005). In rats, similar results were demonstrated in a post-surgical pain model (Kroin et al. 2002, 2004). It seems attractive to propose that COX-2 inhibitors act equally in humans due to a similar cerebrospinal fluid (CSF) and tissue drug uptake compared to animals. However, interspecies differences in blood brain barrier and different degrees of protein binding may alter the drug uptake at these sites of action (Shen et al. 2004; Summerfield et al. 2006). Therefore, clinical investigations in humans are needed before defining the proper dosing of etoricoxib in the perioperative setting. There are only a few recent studies characterizing plasma and CSF pharmacokinetics of COX-2 inhibitors (celecoxib, rofecoxib, and valdecoxib) in humans (Buvanendran et al. 2005; Dembo et al. 2005). A recent pharmacodynamic study with rofecoxib in humans to evaluate CSF interleukin 6 and $\mathrm{PGE}_{2}$ concentrations following orthopedic surgery demonstrated increased levels of these mediators after surgery (Buvanendran et al. 2006). CSF $\mathrm{PGE}_{2}$ concentrations were positively correlated with postoperative pain and the content of $\mathrm{PGE}_{2}$ in tissue exudates correlated with the functional outcome (Buvanendran et al. 2006). Since rofecoxib and valdecoxib have been removed from the market, human data for the remaining COX-2 inhibitors, such as etoricoxib, are missing.

We set out to study the pharmacokinetics of etoricoxib in plasma, CSF, and tissue exudate in order to optimize the dosing and therapeutic benefits of this drug. In this pilot study, we characterized in patients the time course of etoricoxib appearance in CSF and damaged tissue (tissue exudates from surgical site) and determined its effect on $\mathrm{PGE}_{2}$ production at these sites of analgesic action.

\section{Methods}

After approval from the German authorities and the Institutional Ethics Review Board, 12 male and female patients (age 55-80 years) with osteoarthritis undergoing elective primary single hip arthroplasty were consented. All patients were recruited at the Department of Orthopedics, HELIOS Klinikum Berlin-Buch, Germany. The clinical trial is registered at EudraCT (\#2005-003854-80) and at ClinicalTrails.gov (\#NCT00746720). The study was conducted according to the Declaration of Helsinki on biomedical research involving human subjects (Somerset West amendment). All patients gave their informed consent prior to their inclusion in the study. One patient dropped out due to detectable etoricoxib plasma concentrations before receiving the first dose; another patient was unblinded 2 days after drug administration due to an adverse event (hemolytic anemia and hemoglobin decrease) which was unlikely related to the study drug. This patient received diclofenac at day 3 post-surgery as a routine medication and was found positive for diclofenac antibodies.

\section{Patients and study design}

Exclusion criteria were: renal insufficiency (serum creatinine $>1.5 \mathrm{mg} / \mathrm{dL}$ ), recent major trauma or systemic infection (within 3 months), history of usage of corticosteroid medication, or chronic opioids (within 3 months), conditions likely to affect prostaglandin levels and conditions contraindicating spinal anesthesia. In addition, patients were excluded if they had the following characteristics: hypersensitivity to any component of the study medication; uncontrolled hypertension defined as systolic blood pressure $>160 \mathrm{~mm} \mathrm{Hg}$ and diastolic pressure $>90 \mathrm{~mm} \mathrm{Hg}$ during rest at two repeated measurements; congestive heart failure (NYHA II-IV); cerebrovascular disease; established ischemic heart disease (including patients who had recently undergone coronary artery bypass graft surgery or angioplasty); elevated liver function enzymes (threefold above normal range); patients who had developed signs of asthma, acute rhinitis, nasal polyps, angioneurotic edema, or urticaria following the administration of acetylsalicylic acid or other non-steroidal anti-inflammatory drugs; pregnancy and lactation; patients with active peptic ulcerations or active gastro-intestinal bleeding; and inflammatory bowel disease.

Preoperative demographic data were collected and all preoperative medications including dose, route, and duration were recorded. Pain scores were assessed using a numerical rating scale ( 11 point category scale: $0=$ no pain, $10=$ worst possible pain; Downie et al. 1978). Thus, the global (overall) pain and the specific pain for the operative hip at rest and passive movement were obtained before and after surgery.

The study was restricted to a sampling period of $24 \mathrm{~h}$ due to safety reasons (overall sampling volume for CSF and plasma). Patients received the spinal anesthetic bupivacaine $0.5 \%(7.5-10 \mathrm{mg})$ via an intrathecal (IT) catheter placed at the lumbar 3-4 or 4-5 interspace. They were maintained at normothermia in the operating room by supporting means, including warmed intravenous fluids. Postoperatively, 0.01\% bupivacaine was infused intrathecally at a continuous rate superimposed by patient controlled IT boluses. Initial basal infusion rate was $4 \mathrm{~mL} / \mathrm{h}$ with patient controlled boluses of up to $1 \mathrm{~mL} \mathrm{q} 10 \mathrm{~min}$ and a 4-h lockout of $40 \mathrm{~mL}$. The patients were allowed to titrate intrathecal requirements for analgesia using a previously applied analgesic efficacy protocol (Buvanendran et al. 2003). Intravenous morphine 
(or equivalent opioid) was given at a dose of 1-2 $\mathrm{mg}$ for breakthrough pain. Total drug consumption was recorded. If patients had a temperature $>39^{\circ} \mathrm{C}$, oral acetaminophen $1.0 \mathrm{~g}$ was administered after contact with one of the investigators. A standardized surgical technique of non-cemented hip arthroplasty was used for all patients.

As the study was focused on the PK data from three matrixes during absorption period, only four patients served as placebo controls. On postoperative day 1, eight patients received oral etoricoxib $120 \mathrm{mg}$ at $7.00 \mathrm{AM}$ and four patients received a placebo. The study was blinded to patients and the investigators, but not to the analytical department. Blood $(3 \mathrm{~mL})$ and CSF samples $(0.5 \mathrm{~mL})$ were collected before and at the following time points after drug administration: 1.0, 2.0, 3.0, 4.0, 8.0, 12.0, and $24 \mathrm{~h}$ (eight time points). The initial $1 \mathrm{ml}$ of each CSF sample was discarded to account for dead space in the catheter and to avoid possible dilution artifacts regarding the intrathecally applied bupivacaine. The postoperative analgesic IT solution was administered to provide continuous analgesia for the patients between sampling time points.

Tissue exudates (hip drain) were collected at 0.0 (before), 1.0, 3.0, 8.0, 12.0, and $24 \mathrm{~h}$ after drug administration. One hour before the scheduled collection time, the Redon drain system (B. Braun AG, Melsungen, Germany) was emptied and the exudate was collected over the next $60 \mathrm{~min}$ (additional sampling times at 2.0, 7.0, 11.0, and $23 \mathrm{~h}$ post-medication). Drain fluids were centrifuged and the supernatant frozen at $-30^{\circ} \mathrm{C}$ and sent for analysis.

\section{Pharmacokinetic analysis}

Following oral etoricoxib, pharmacokinetic parameters were determined in plasma, tissue exudate, and CSF in each subject using a liquid chromatography-tandem mass spectrometry (LC-MS/MS). The analytical method was adapted from published work on plasma using phenazone as an internal standard (Brautigam et al. 2003). The detection was performed on API 4000 (Applied Biosystems, Langen, Germany) and determination of the limits of quantification (LOQ) for etoricoxib plasma, CSF, and tissue exudates were carried out according to the Food and Drug Administration (FDA) guidelines (US Department of Health and Human Services, 2001). The LOQ for etoricoxib was $0.2 \mathrm{ng} / \mathrm{mL}$ in all three matrixes. The analytical method was validated over the concentration range $0.2-$ $200 \mathrm{ng} / \mathrm{mL}$. The area under the curve (AUC) $[\mathrm{ng} \cdot \mathrm{h} / \mathrm{mL}]$ from 0 to $24 \mathrm{~h}$ was calculated for both CSF and plasma data using the linear trapezoidal method. The fraction of plasma etoricoxib in the CSF was calculated from the ratio of $\mathrm{AUC}_{\mathrm{CSF}}$ to $\mathrm{AUC}_{\text {plasma }}$ at each sampling time.

$\mathrm{PGE}_{2}$ analysis from tissue samples was performed using enzyme linked immunoassay kits (Cayman Chemical, MI,
USA). The LOQ for $\mathrm{PGE}_{2}$ was $15 \mathrm{pg} / \mathrm{mL}$. CSF samples were analyzed for $\mathrm{PGE}_{2}$ using LC-MS/MS methods, which were developed in this study using a stable isotope of prostaglandin $\mathrm{D}_{2}-\mathrm{d}_{4}$. The solid phase extraction method and the LC-MS/MS conditions were adjusted to our API 4000 system using previous publications (Nithipatikom et al. 2003; Schmidt et al. 2005). The lower LOQ was $25 \mathrm{pg} / \mathrm{mL}$ and the upper LOQ was $200 \mathrm{pg} / \mathrm{mL}$ according to FDA guidelines (US Department of Health and Human Services 2001). The $\mathrm{PGE}_{2}$ concentrations at the central (CSF) and peripheral (tissue exudate) sites over time were compared between the study groups.

\section{Secondary parameters}

Pain scores at rest and passive movement of the operated hip were assessed at 4.0, 8.0, 12, 24, 26, 32, and 48 h time points after study drug administration. The total IT medication consumption, the number of patient activated requests, delivered boluses, and time of requests were documented. Tympanic temperature was monitored at the preoperative visit and at each blood and CSF measurement time points.

Hematology comprising a complete blood count with counts of leukocytes and platelets was obtained preoperatively and postoperatively as per routine standard care. Blood products transfused in the perioperative phase were recorded. In addition, coagulation parameters were measured and recorded (preoperatively and postoperatively). Patients rated their sleep disturbance due to pain at $24 \mathrm{~h}$ after surgery $(0=$ no sleep disturbance to $10=$ greatest sleep disturbance; Buvanendran et al. 2003).

\section{Statistical analysis and sample size estimation}

Demographic and other univariate data were analyzed using $t$ tests, $\chi^{2}$ tests, and Fisher's exact tests, the MantelHaenszel test, or the Mann-Whitney $U$-test, contingent on the scale and distributional characteristics of the variables, and applying the Bonferroni step-down correction method to adjust for multiple comparisons. Unless otherwise indicated, descriptive statistics are reported as mean and standard deviation (SD) for continuous normally distributed variables, or as median and interquartile range for ordinal or non-normally distributed variables, while dichotomous variables are reported using counts and/or percentages. Outcomes with measures at multiple time points were analyzed using repeated-measures analysis of variance with an auto-regressive covariance structure to account for the correlated nature of individual patient contributions.

Initial pilot data obtained with rofecoxib indicated a significant reduction in $\mathrm{CSF} \mathrm{PGE}_{2}$ concentrations, but with variability differing between the two groups (Buvanendran 
et al. 2006). In an effort to address this issue in our actual study, the treatment group was oversampled at a rate of 2 to 1 as compared to the placebo group. Assuming a threefold reduction in $\mathrm{CSF}^{\mathrm{PGE}} \mathrm{PG}_{2}$ concentrations with a $\mathrm{SD}$ of $60 \mathrm{pg} /$ $\mathrm{mL}$ for the treatment group and $40 \mathrm{pg} / \mathrm{mL}$ for the placebo, a total sample size of 12 , with eight treatment subjects and four placebo subjects, will provide $84 \%$ power to detect a significant difference for a two-sided $t$ test [data for sample size estimation were taken from (Buvanendran et al. 2006)]. Relationships between variables were evaluated using the Pearson product-moment correlation. $P<0.05$ was used to determine statistical significance. All statistical analyses were performed using SAS version 9.1 (SAS Institute Inc, Cary, NC, USA).

\section{Results}

An analysis of the demographic variables for the two groups of patients shown in Table 1 demonstrates that there were no significant differences. The duration of surgery and blood loss for the two groups was also not different. For the active treatment group, hematological parameters such as hemoglobin were slightly lower in the postoperative period compared to preoperative values. There were no meaningful differences in postoperative pain and opioid consumption, neither in the pain scores at rest globally and also during movement between the two groups of patients. During the $48 \mathrm{~h}$ postoperative period, the amount of intrathecal drug (IT boluses of bupivacaine) administered, titrated to provide postoperative analgesia, did not differ

Table 1 Demographic characteristics of the patients

\begin{tabular}{|c|c|c|c|}
\hline & \multirow{2}{*}{$\frac{\text { Placebo }(n=3)^{\mathrm{a}}}{\text { Mean }(\mathrm{SD})}$} & \multirow{2}{*}{$\frac{\text { Etoricoxib }(n=8)}{\text { Mean }(\mathrm{SD})}$} & \multirow[t]{2}{*}{$P$ value } \\
\hline & & & \\
\hline Age (yr) & $67.4(2.4)$ & $72.1(5.4)$ & 0.1963 \\
\hline Weight (kg) & $88.5(16.3)$ & $77.4(8.9)$ & 0.2031 \\
\hline Height $(\mathrm{cm})$ & $171(9)$ & $163(8)$ & 0.2442 \\
\hline Sex (counts) & & & $0.3869^{\mathrm{b}}$ \\
\hline Female/male & $1 / 2$ & $5 / 3$ & \\
\hline Race (counts) & & & ND \\
\hline Caucasian & $3(100 \%)$ & $8(100 \%)$ & \\
\hline Duration of surgery (min) & $56(19)$ & $39(6)$ & 0.2609 \\
\hline Intra-OP BL (mL) & $300(0)^{\mathrm{c}}$ & $440(114)^{\mathrm{c}}$ & 0.0516 \\
\hline
\end{tabular}

Values are mean (standard deviation) unless otherwise indicated $S D$ standard deviation, Intra-OP $B L$ blood loss during surgery, $N D$ not done (statistic cannot be computed)

${ }^{a}$ One patient in the placebo group dropped out due to clinical reasons

${ }^{\text {b }}$ Chi-square test, due to low counts $P$ value may be biased

${ }^{\mathrm{c}}$ Due to missing values $n=2 / n=5$ in the placebo/etoricoxib group between the two groups. Similarly, there was no difference in the use of additional analgesics, but the study was not designed to detect such differences as both groups received standard IT and parenteral pain medication at this state post-surgery.

\section{Prostaglandin $\mathrm{E}_{2}$ concentrations}

We observed a significant difference in the $\mathrm{PGE}_{2}$ concentration in the tissue exudate between the etoricoxib and placebo group despite the small number of patients in the placebo group (Fig. 1 and Table 2). This difference became significant in the samples retrieved $5 \mathrm{~h}$ after medication. It lasted $18 \mathrm{~h}$ till the end of the observation period. There was a time lag between exudate production and sample recovery from the Redon drain. The material sampled at, e.g., $5 \mathrm{~h}$ was produced about $2 \mathrm{~h}$ after medication. Altogether, we found a negative correlation $(R=-0.7 ; P=0.02)$ between the concentration of etoricoxib and that of $\mathrm{PGE}_{2}$ in the tissue exudates.

The CSF $\mathrm{PGE}_{2}$ concentrations were below the quantification limit of the LC-MS/MS method in most cases. Therefore, AUCs could not be calculated and group analysis was not performed for this parameter.

\section{Etoricoxib concentrations}

A summary of the pharmacokinetic data is given in Table 3. The 24-h concentration-time curves of etoricoxib in plasma, CSF, and tissue exudate are shown in Fig. 2 with semilogarithmic presentation. Data with linear scaling are given in Figs. 1 and 3a, respectively. The drug concentration in the CSF lagged behind that of plasma. In plasma, etoricoxib concentrations peaked at $1 \mathrm{~h}$ on average (see Fig. 2). At that time, CSF concentrations were measurable, but reached only about a third (34\%) of the peak concentration which was observed at $8 \mathrm{~h}$ (Fig. 3a and Table 3). In both compartments, a plateau was reached after about $2 \mathrm{~h}$ (compare Fig. 2). The CSF/plasma concentration ratio of the drug in absolute terms was 0.016 at $1 \mathrm{~h}$ and increased to 0.030 and 0.057 at 2 and $4 \mathrm{~h}$, respectively. On time average, the maximum $\mathrm{CSF} /$ plasma ratio (0.063) occurred at $8 \mathrm{~h}$. Individual maximum concentration ratios were observed to be $7.3 \%( \pm 2.1)$ between 3 and $12 \mathrm{~h}$ postdrug administration. The mean $\mathrm{CSF} /$ plasma ratio with respect to $\mathrm{AUC}_{0-24 \mathrm{~h}}$ was $4.4 \%$ (see Table 3 and Fig. $3 \mathrm{~b}$ ).

The median CSF lag time with respect to $50 \%$ of the peak concentration in plasma was 0.5 ( 1 if patient R09 is included) h, range 0-2 (7 if R09 included) h. One patient (R09) showed an extended lag time ( $7 \mathrm{~h}$ ) which may be due to a second fractionate absorption resulting in a higher CSF peak concentration $(108 \mathrm{ng} / \mathrm{mL})$ at $8 \mathrm{~h}$ postmedication (see Table 4). 
Fig. 1 Time course of etoricoxib and prostaglandin $\mathrm{E}_{2}$ $\left(\mathrm{PGE}_{2}\right)$ concentrations in tissue exudates. $\mathrm{PGE}_{2}$ concentrations are shown as differences to baseline values. Sample times are midpoints of collection intervals (means \pm SEM; placebo group $n=3$; etoricoxib group $n=8)$. Absolute $\mathrm{PGE}_{2}$ concentrations and statistical data are given in Table 1

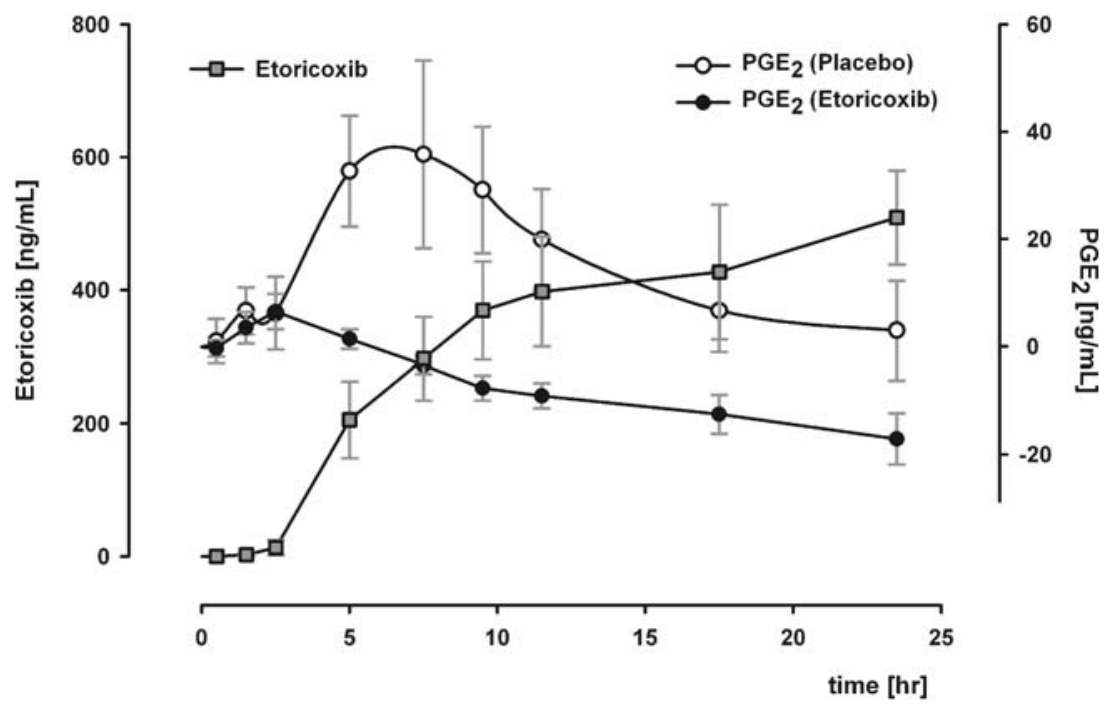

Tissue exudate concentrations for etoricoxib appeared to lag behind plasma and CSF with virtually no drug detected at $2.5 \mathrm{~h}$ (Figs. 1 and 2). The virtual lag time (without correction for the delay of sampling) for $50 \%$ peak concentration ranged between 1.5 and $6.5 \mathrm{~h}$ (median $4 \mathrm{~h}$; see Table 4).

\section{Discussion}

This is the first study in humans to characterize the pharmacokinetics of the COX-2 inhibitor etoricoxib in the CSF, plasma, and tissue exudate simultaneously and in conjunction with effect data from the putative sites of action. The main finding of this pilot study is that plasma etoricoxib enters the CSF with a lag time of about $1 \mathrm{~h}$ and reaches a CSF/plasma concentration ratio of approximately $5 \%$. At the site of surgery, we observed that $\mathrm{PGE}_{2}$ production was still high 1 day after surgery. In the placebo group, it increased further whereas it decreased significantly in the treatment group beginning with the appearance of etoricoxib in the wound fluid.

It was not the aim of this study to investigate the analgesic effect of etoricoxib in patients. This is obvious from the fact that the patients received complete routine
Table 2 Statistical summary for $\mathrm{PGE}_{2}$ concentrations $[\mathrm{ng} / \mathrm{mL}]$ in tissue exudate
All $<$ LOQ values set to max of $25 \mathrm{pg} / \mathrm{mL}$

${ }^{a}$ Statistically significant at alpha $=0.05$

${ }^{\mathrm{b}}$ One patient in the placebo group dropped out due to clinical reasons

${ }^{\mathrm{c}}$ Time points are midpoints of collection intervals

$\mathrm{PGE}_{2}=$ prostaglandin $\mathrm{E}_{2} ; \mathrm{SD}=$ standard deviation

$\mathrm{PGE}_{2}$ values were modeled using repeated measures analysis of variance. Maximum likelihood parameter estimates were generated using an autoregressive mixture model.

\begin{tabular}{|c|c|c|c|}
\hline & \multirow{2}{*}{$\frac{\text { Placebo }(n=3)^{\mathrm{b}}}{\text { Mean (SD) }}$} & \multirow{2}{*}{$\frac{\text { Etoricoxib }(n=8)}{\text { Mean }(\mathrm{SD})}$} & \multirow[t]{2}{*}{$P$ value } \\
\hline & & & \\
\hline \multicolumn{4}{|c|}{ Overall difference for all values } \\
\hline $\mathrm{PGE}_{2}$ Hip $(n=88)$ & $33.7(22.7)$ & $11.9(10.2)$ & $<.0001$ \\
\hline \multicolumn{4}{|l|}{ Regression model } \\
\hline \multicolumn{4}{|l|}{$\mathrm{PGE}_{2}$ Hip } \\
\hline Interaction & & & $<.0001^{\mathrm{a}}$ \\
\hline Main effect & & & $0.0073^{\mathrm{a}}$ \\
\hline \multicolumn{4}{|c|}{ Time points contrasts ${ }^{\mathrm{c}}$} \\
\hline Pre & $15.4(14.6)$ & $7.7(5.4)$ & 0.3158 \\
\hline$-0.5 \mathrm{~h}$ & $21.2(5.0)$ & $15.1(9.1)$ & 0.4406 \\
\hline $0.5 \mathrm{~h}$ & $20.1(3.5)$ & $18.1(8.8)$ & 0.4103 \\
\hline $1.5 \mathrm{~h}$ & $27.8(5.5)$ & $24.4(10.5)$ & 0.2002 \\
\hline $2.5 \mathrm{~h}$ & $27.4(10.9)$ & $20.9(16.1)$ & 0.4170 \\
\hline $5.0 \mathrm{~h}$ & $53.9(24.5)$ & $16.9(13.6)$ & $<.0001^{\mathrm{a}}$ \\
\hline $7.5 \mathrm{~h}$ & $57.0(39.8)$ & $12.1(9.3)$ & $<.0001^{\mathrm{a}}$ \\
\hline $9.5 \mathrm{~h}$ & $50.4(27.7)$ & $7.9(6.0)$ & $<.0001^{\mathrm{a}}$ \\
\hline $11.5 \mathrm{~h}$ & $41.1(24.1)$ & $6.4(5.1)$ & $0.0001^{\mathrm{a}}$ \\
\hline $17.5 \mathrm{~h}$ & $27.9(20.1)$ & $6.2(6.2)$ & $0.0061^{\mathrm{a}}$ \\
\hline $23.5 \mathrm{~h}$ & $24.2(23.0)$ & $2.3(0.7)$ & $0.0141^{\mathrm{a}}$ \\
\hline
\end{tabular}


Table 3 Pharmacokinetic parameters of etoricoxib comparing cerebrospinal fluid (CSF) and plasma data

\begin{tabular}{|c|c|c|c|}
\hline & \multicolumn{2}{|l|}{ Plasma } & \multirow{2}{*}{$\begin{array}{l}\text { CSF } \\
n=5^{\mathrm{a}}\end{array}$} \\
\hline & $n=8$ (all patients) & $n=5^{\mathrm{a}}$ & \\
\hline $\mathrm{AUC}_{0-24 \mathrm{~h}}[\mathrm{~h} \times \mathrm{ng} / \mathrm{mL}]^{\mathrm{b}}$ & $22,197(5,780)$ & $22,587(5,759)$ & $955(354)$ \\
\hline$t_{\max }[\mathrm{h}]^{\mathrm{c}}$ & $3(1-24)$ & $4(1-24)$ & $8(2-12)$ \\
\hline$c_{\max }[\mathrm{ng} / \mathrm{mL}]^{\mathrm{b}}$ & $1735.1(1206.4)$ & $1437.6(533.8)$ & $68.4(30.6)$ \\
\hline $\mathrm{CSF} /$ plasma ratio $\mathrm{AUC}_{0-24 \mathrm{~h}}[\%]^{\mathrm{d}}$ & & $4.4(2-7)$ & \\
\hline$t_{\max }[\mathrm{h}]$ for CSF/plasma conc. ratio ${ }^{\mathrm{c}}$ & & $8(3-12)$ & \\
\hline $\mathrm{CSF} /$ plasma conc. ratio [\%] at $t_{\max } \mathrm{b}$ & & $6.3(2.0)$ & \\
\hline Max. CSF/plasma conc. ratio $[\%]^{\mathrm{e}}$ & & $7.3(2.1)$ & \\
\hline
\end{tabular}

$S D$ standard deviation, conc. concentration

${ }^{a}$ Subgroup analysis without data from three patients due to incomplete CSF samples

${ }^{\mathrm{b}}$ Mean $( \pm \mathrm{SD})$

${ }^{\mathrm{c}}$ Median (range)

${ }^{\mathrm{d}}$ Individual $\mathrm{CSF} /$ plasma ratios were calculated using $\mathrm{AUC}_{0-24 \mathrm{~h}}$; mean (range) data are given in percentage values

${ }^{\mathrm{e}} \mathrm{Max}$. CSF/plasma ratios were calculated using individual maximal concentration ratios (mean $\pm \mathrm{SD}$ ) data are given in percentage values

analgesic treatment and that etoricoxib was administered $24 \mathrm{~h}$ after surgery, i.e., at a time when postoperative pain has subsided considerably and body functions have recovered. We observed no perioperative side effects related to the administration of etoricoxib. Signs of higher blood loss in the etoricoxib compared to the placebo group (see Table 1) were not caused by the drug, since they occurred before drug administration.

Our pharmacokinetic results are comparable to those seen in healthy volunteers, but indicate differences as well. Fast absorption and slow elimination is seen in our elderly postoperative patients, too, but the time to peak is more variable. Consistent with data published previously, a twinpeak pattern was observed in the plasma concentrationtime curve of etoricoxib after administered orally to healthy subjects (Dallob et al. 2003; Agrawal et al. 2003a). Possible mechanisms for secondary peaks include biphasic dissolution or fractionated gastric emptying, and presence of two different absorption sites or enterohepatic recycling. All may be pertinent to our results.

In addition, we could show that a fast transfer of effective concentrations of etoricoxib into the CNS fluid and into the tissue exudates occurs. Indeed, meaningful (COX-2 inhibitory) CSF concentrations were reached
Fig. 2 Etoricoxib concentrations in three different matrixes (plasma, cerebrospinal fluid $[\mathrm{CSF}]$ and tissue exudates, semi logarithmical presentation). Not quantifiable concentrations were set to the LOQ of $0.2 \mathrm{ng} / \mathrm{mL}$ (means $\pm \mathrm{SEM} ; n=8$ ). Tissue exudate sampling times are midpoints of collection intervals. Note: it took about $2 \mathrm{~h}$ until tissue exudate reached the end of the Redon drain (sample recovery)

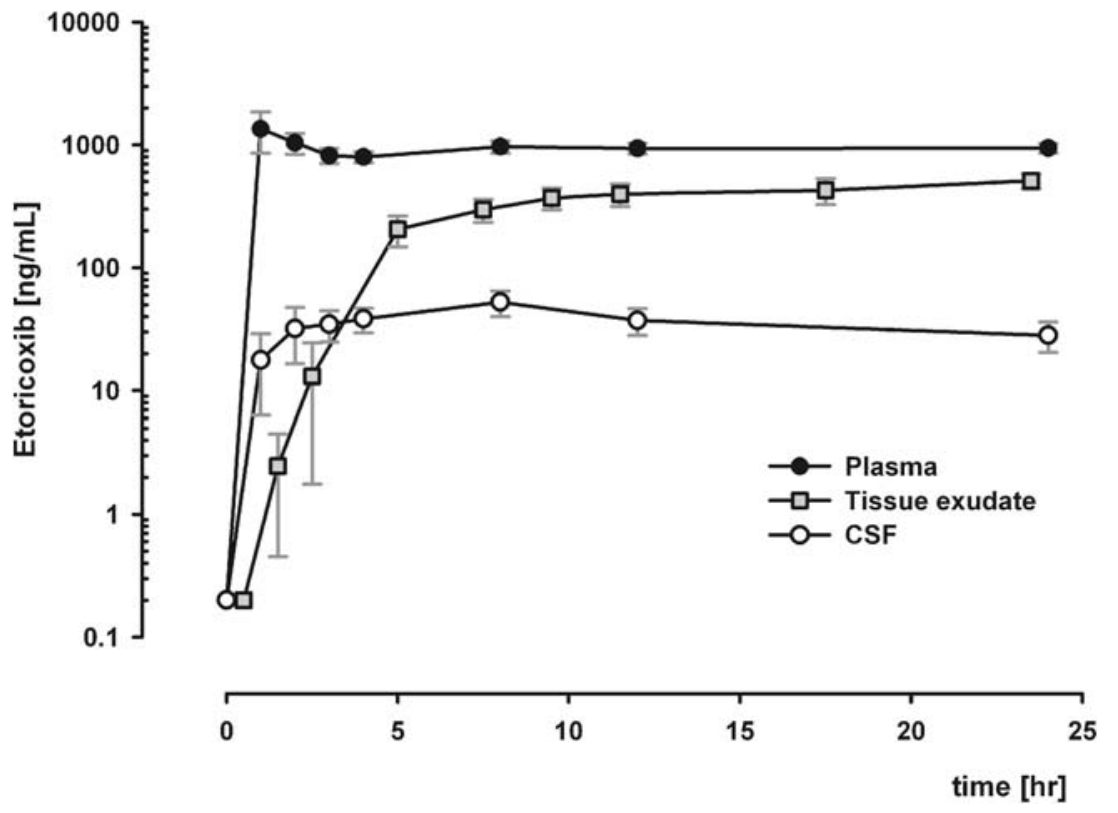


Fig. 3 a Plasma and cerebrospinal fluid (CSF) concentrations after administration of $120 \mathrm{mg}$ etoricoxib orally to eight patients (linear presentation, means \pm SEM). $\mathbf{b}$

Corresponding time course of individual and mean CSF/plasing the relative etoricoxib penetration into the CSF; mean data (black) are based on complete data sets from five patients only, but all individual patient data $(n=8)$ are presented (patients data, gray); descriptive data are given in Table 3 ma concentration ratios indicat-
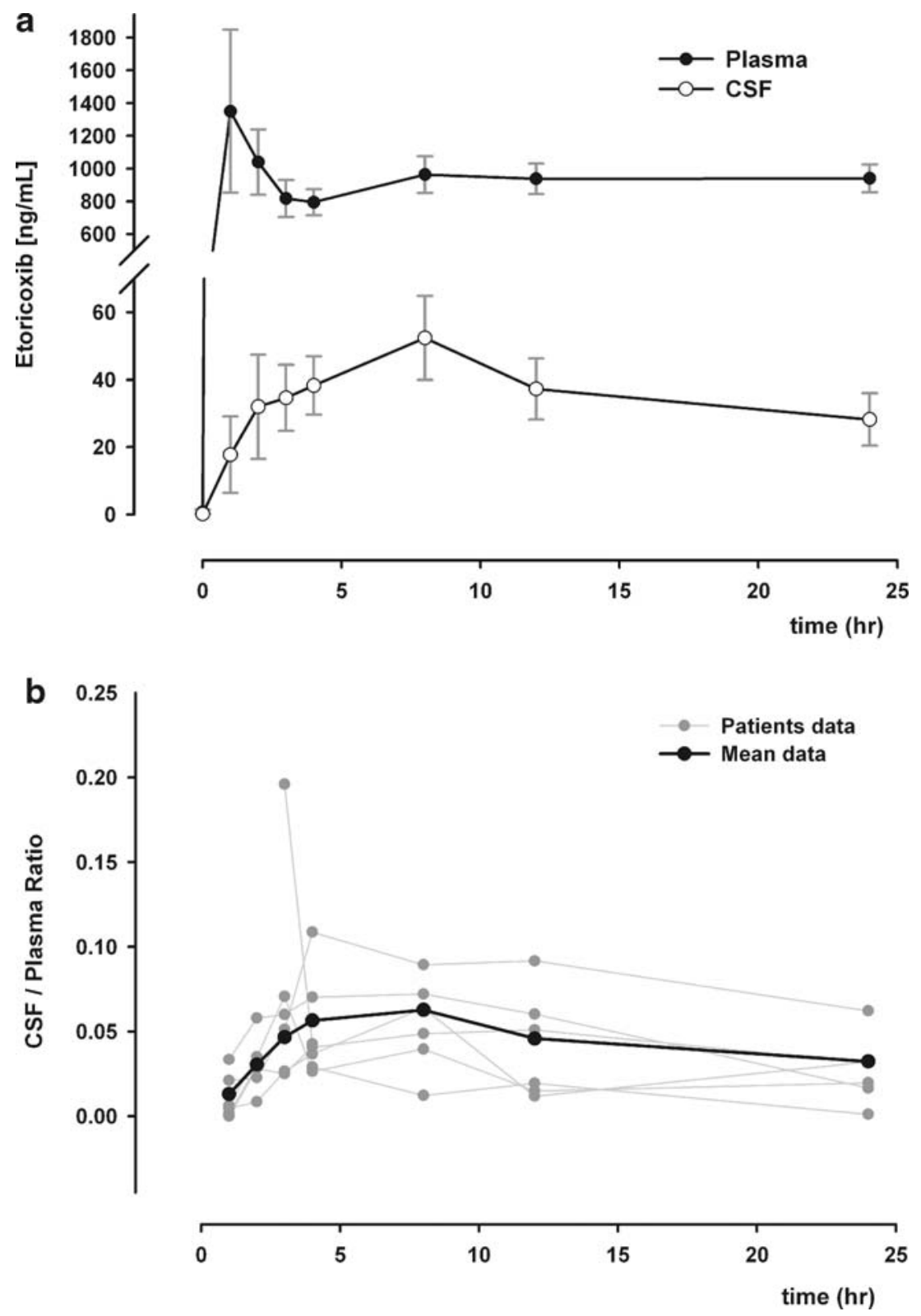

within $2 \mathrm{~h}$ in nearly all patients. In absolute terms, the concentration in CSF fluid amounted to about a $1 / 20$ of that seen at corresponding times in plasma $\left(\mathrm{AUC}_{0-24 \mathrm{~h}}\right.$ and max. concentration ratios; Table 3 and Fig. $3 b$ ). The maximum etoricoxib CSF/plasma ratio (6\%) occurred at $8 \mathrm{~h}$. Similar ratios were seen with valdecoxib (4\%) and celecoxib (1\%) at $6 \mathrm{~h}$ after drug administration. The ratio is reported somewhat higher for rofecoxib (15-20\%) with a

Table 4 Individual lag times [h] of etoricoxib for tissue exudate and cerebrospinal fluid (CSF)

\begin{tabular}{|c|c|c|c|c|c|c|c|c|c|c|}
\hline Patient \# & R01 & R02 & R05 & R06 & R07 & R09 & $\mathrm{R} 10$ & $\mathrm{R} 12$ & MEDIAN & MEAN \\
\hline Plasma vs. Tissue exudate & 4 & 4 & ND & 1.5 & 6.5 & ND & 3 & ND & 4 & 3.8 \\
\hline Plasma vs. CSF & 1 & 2 & (2) & 0 & (3) & 7 & $(0)$ & 0 & 1 & 2 \\
\hline
\end{tabular}

$N D$ sample not done, () invalid data due to missing values

Lag times were calculated with respect to $50 \%$ of peak concentrations 
corresponding lag time (Buvanendran et al. 2005; Dembo et al. 2005). The (time averaged) maximum CSF concentration was nearly $70 \mathrm{ng} / \mathrm{mL}$ for etoricoxib (Table 3), which exceeds the concentrations found in CSF for rofecoxib (40$60 \mathrm{ng} / \mathrm{mL})$, valdecoxib $(25 \mathrm{ng} / \mathrm{mL})$, and celecoxib $(2 \mathrm{ng} / \mathrm{mL})$ after an oral dose for acute pain (Buvanendran et al. 2005; Dembo et al. 2005). This reflects the higher dose of etoricoxib (120 mg), as compared to rofecoxib $(50 \mathrm{mg})$ and valdecoxib $(40 \mathrm{mg})$ and the low bioavailability of celecoxib (20-60\% at $200 \mathrm{mg}$; Brune and Hinz 2004; Hinz et al. 2007). CSF fluid is almost free of plasma proteins, and etoricoxib (as well as other COX-2 inhibitors), being highly bound $(92 \%)$ to plasma proteins (Agrawal et al. 2003b), should reach concentrations in CSF similar to the free fraction in plasma. It is commonly accepted that uptake into the CNS is restricted to the unbound plasma fraction (Wilkinson 1983). We estimated the CSF/plasma ratio of the unbound fractions $(\mathrm{CSF} / \mathrm{Pu})$ at equilibrium (2$24 \mathrm{~h})$. It was about $0.56(\mathrm{SD} \pm 0.24)$. A similar brain/blood ratio for etoricoxib was reported in animals $(0.66 ; \mathrm{SD} \pm 0.04)$ (Summerfield et al. 2006). Both estimates hint at a comparable CNS transfer rate of etoricoxib in man and rats.

$\mathrm{CSF} / \mathrm{Pu}$ ratios for rofecoxib, valdecoxib, and celecoxib were reported before. The estimates range between 1.5 and 1.7 (Dembo et al. 2005). These data, clearly above 1.0, suggest an accumulation of these more lipophilic drugs in the CSF (Shen et al. 2004). The data quoted here were derived, however, in an unusual study. The volunteers received therapeutic doses of all three drugs at the same time. Therefore, complex interactions appear possible (Dembo et al. 2005).

The CSF concentrations of etoricoxib observed can be related to those which are required for $50 \%$ of $\mathrm{COX}-2$ inhibition $\left(\mathrm{IC}_{50}\right)$. Different $\mathrm{IC}_{50}$ values for several COX-2 inhibitors are reported. Most derive from in vitro assays including the original whole blood assay introduced by Patrignani (Patrignani et al. 1994). In this version of the assay, drug is added to human blood in vitro and the $\mathrm{IC}_{50}$ values defined. The published in vitro $\mathrm{IC}_{50}$ data for etoricoxib are lower than ex vivo results. In vitro data vary considerably from 0.26 to $0.5 \mu \mathrm{M}$ for etoricoxib, from 0.19 to $0.93 \mu \mathrm{M}$ for celecoxib, or from 0.1 to $0.65 \mu \mathrm{M}$ for valdecoxib (Tacconelli et al. 2002; Gierse et al. 2005; Esser et al. 2005; Ushiyama et al. 2008). Data from ex vivo whole blood assays are limited or missing in order to compare between different COX-2 inhibitors. In this version of the assay, the drugs are given to volunteers and the COX-2 inhibition will be measured in blood containing the drug (Patrignani et al. 1994; Panara et al. 1998). In a recent study, using the ex vivo whole blood assay, Dallob determined the $\mathrm{IC}_{50}$ to be $1 \mu \mathrm{M}$ (about $360 \mathrm{ng} / \mathrm{mL}$ ) after a single dose of $120 \mathrm{mg}$ etoricoxib (Dallob et al. 2003).

In our patients, meaningful (probably effective) concentrations of etoricoxib $(>360 \mathrm{ng} / \mathrm{mL})$ appeared during the first hour in plasma applying the conservative ex vivo $\mathrm{IC}_{50}$ data from Dallob et al. (Dallob et al. 2003). We observed comparable concentrations [free fraction 8\% (Agrawal et al. 2003b)] of etoricoxib in the CSF $(>29 \mathrm{ng} / \mathrm{mL} ;>0,08 \mu \mathrm{M})$ $1 \mathrm{~h}$ later. This CNS lag time compares favorably with the onset of antipyretic action of etoricoxib at about $2 \mathrm{~h}$ postdose in monkeys (Riendeau et al. 2001). Former studies in patients have shown that etoricoxib interferes with surgical pain within the first $2 \mathrm{~h}$ after administration (Clarke et al. 2009). In contrast to this observation are those published by Smirnov et al. (Smirnov et al. 2008). These authors investigated the effect of etoricoxib after thyroid surgery and found that it was not analgesic before $6 \mathrm{~h}$ after surgery. The difference may be explained by the fact that patients with thyroid dysfunction do not suffer from pain before surgery. Consequently, only surgery will induce COX-2 in the central nervous system de novo which, according to our knowledge, should take a few hours. That would explain the delayed onset despite probably fast absorption of etoricoxib in these patients.

A former investigation employing rofecoxib demonstrated that $\mathrm{PGE}_{2}$ concentrations in the CSF started to decline shortly after drug administration (Buvanendran et al. 2006). In contrast to this previous study, we sampled CNS fluid not directly following surgery, but $24 \mathrm{~h}$ thereafter. We found only low $\mathrm{PGE}_{2}$ concentrations (at the quantification limit) in CSF of treated and not-treated patients. These low concentrations appeared to decrease further in several patients on etoricoxib at or below the detection limit of our assay. Therefore, these data were not shown.

However, we observed increasing $\mathrm{PGE}_{2}$ concentrations at the site of surgery in the placebo group. Obviously, COX-2 was already induced following surgery at the day before. Consequently, we could observe an immediate action of etoricoxib when entering the inflamed tissue. Similar effects have been reported for rofecoxib, but without simultaneous sampling of $\mathrm{PGE}_{2}$ and drug concentration data at the wound site (Buvanendran et al. 2005, 2006). It should be kept in mind that the appearance and persistence of etoricoxib concentrations sufficient to interfere with $\mathrm{PGE}_{2}$ production may be instrumental for achieving inhibition of heterotopic ossification which has been shown for several drugs, including COX-2 selective inhibitors, but not yet for etoricoxib (Sodemann et al. 1990; Barthel et al. 2002; Buvanendran et al. 2007).

In conclusion, our pilot study supports the contention that the selective COX-2 inhibitor etoricoxib may be suitable for perioperative treatment in patients who are not at high risk for cardiovascular conditions. Indeed, we found that etoricoxib reaches meaningful CSF and wound fluid concentrations shortly after administration. Following the appearance of effective concentrations in these compartments, inhibition of prostaglandin production was observed. 
It appears plausible that this goes along with antihyperalgesia. Based on the results presented, it is planned to investigate the perioperative application of etoricoxib in a further study aimed at defining the analgesic effectiveness of etoricoxib under these conditions. The drug will be given before surgery and the postoperative pharmacokinetics and analgesic effects monitored thereafter.

\begin{abstract}
Acknowledgment The authors would like to thank Dr. Juergen Kreutzer (Department of Neurosurgery, University of ErlangenNuremberg, Germany) and Dr. Hans Parsch (Central Laboratory, University of Erlangen-Nuremberg, Germany) for their contribution during CSF analysis. We have to thank Dr. Detlef Becker (Central Laboratory, Helios Klinikum Berlin-Buch, Germany) for hematology and blood chemistry analysis. We also thank Professor Martin F. Fromm for guidance of the analytical part of the study, Martin Gillich for excellent technical assistance during LC-MS/MS analysis, Stephanie Link for performing the immunoassays, and all patients for their participation. The work was supported by a grant from MSD Sharpe and Dohme GmbH (Haar, Germany) to Professor Kay Brune.
\end{abstract}

Open Access This article is distributed under the terms of the Creative Commons Attribution Noncommercial License which permits any noncommercial use, distribution, and reproduction in any medium, provided the original author(s) and source are credited.

\section{References}

Agrawal NG, Porras AG, Matthews CZ, Rose MJ, Woolf EJ, Musser BJ, Dynder AL, Mazina KE, Lasseter KC, Hunt TL, Schwartz JI, McCrea JB, Gottesdiener KM (2003a) Single- and multiple-dose pharmacokinetics of etoricoxib, a selective inhibitor of cyclooxygenase-2, in man. J Clin Pharmacol 43:268-276

Agrawal NG, Rose MJ, Matthews CZ, Woolf EJ, Porras AG, Geer LA, Larson PJ, Cote J, Dilzer SC, Lasseter KC, Alam I, Petty KJ, Gottesdiener KM (2003b) Pharmacokinetics of etoricoxib in patients with hepatic impairment. J Clin Pharmacol 43:1136-1148

Barthel T, Baumann B, Noth U, Eulert J (2002) Prophylaxis of heterotopic ossification after total hip arthroplasty: a prospective randomized study comparing indomethacin and meloxicam. Acta Orthop Scand 73:611-614

Brautigam L, Nefflen JU, Geisslinger G (2003) Determination of etoricoxib in human plasma by liquid chromatography-tandem mass spectrometry with electrospray ionisation. J Chromatogr B Analyt Technol Biomed Life Sci 788:309-315

Brune K, Hinz B (2004) Selective cyclooxygenase-2 inhibitors: similarities and differences. Scand J Rheumatol 33:1-6

Buvanendran A, Kroin JS, Tuman KJ, Lubenow TR, Elmofty D, Moric M, Rosenberg AG (2003) Effects of perioperative administration of a selective cyclooxygenase 2 inhibitor on pain management and recovery of function after knee replacement: a randomized controlled trial. JAMA 290:2411-2418

Buvanendran A, Kroin JS, Tuman KJ, Lubenow TR, Elmofty D, Luk P (2005) Cerebrospinal fluid and plasma pharmacokinetics of the cyclooxygenase 2 inhibitor rofecoxib in humans: single and multiple oral drug administration. Anesth Analg 100:1320-1324, table

Buvanendran A, Kroin JS, Berger RA, Hallab NJ, Saha C, Negrescu C, Moric M, Caicedo MS, Tuman KJ (2006) Upregulation of prostaglandin E2 and interleukins in the central nervous system and peripheral tissue during and after surgery in humans. Anesthesiology 104:403-410
Buvanendran A, Kroin JS, Berger RA (2007) Preoperative cyclooxygenase- 2 inhibitor treatment reduces the incidence of heterotopic ossification after hip arthroplasty: six-month followup. Anesthesiology 107:358-359

Clarke R, Derry S, Moore RA, McQuay HJ (2009) Single dose oral etoricoxib for acute postoperative pain in adults. Cochrane Database Syst RevCD004309

Dallob A, Hawkey CJ, Greenberg H, Wight N, De SP, Waldman S, Wong P, DeTora L, Gertz B, Agrawal N, Wagner J, Gottesdiener K (2003) Characterization of etoricoxib, a novel, selective COX-2 inhibitor. J Clin Pharmacol 43:573-585

Dembo G, Park SB, Kharasch ED (2005) Central nervous system concentrations of cyclooxygenase-2 inhibitors in humans. Anesthesiology 102:409-415

Dirig DM, Yaksh TL (1999) Spinal synthesis and release of prostanoids after peripheral injury and inflammation. Adv Exp Med Biol 469:401-408

Dolan S, Kelly JG, Huan M, Nolan AM (2003) Transient upregulation of spinal cyclooxygenase- 2 and neuronal nitric oxide synthase following surgical inflammation. Anesthesiology 98:170-180

Downie WW, Leatham PA, Rhind VM, Wright V, Branco JA, Anderson JA (1978) Studies with pain rating scales. Ann Rheum Dis $37: 378-381$

Esser R, Berry C, Du Z, Dawson J, Fox A, Fujimoto RA, Haston W, Kimble EF, Koehler J, Peppard J, Quadros E, Quintavalla J, Toscano K, Urban L, van DJ, Zhang X, Zhou S, Marshall PJ (2005) Preclinical pharmacology of lumiracoxib: a novel selective inhibitor of cyclooxygenase-2. Br J Pharmacol 144:538-550

Gierse JK, Zhang Y, Hood WF, Walker MC, Trigg JS, Maziasz TJ, Koboldt CM, Muhammad JL, Zweifel BS, Masferrer JL, Isakson PC, Seibert K (2005) Valdecoxib: assessment of cyclooxygenase2 potency and selectivity. J Pharmacol Exp Ther 312:1206-1212

Hinz B, Renner B, Brune K (2007) Drug insight: cyclo-oxygenase-2 inhibitors - a critical appraisal. Nat Clin Pract Rheumatol 3:552560

Kroin JS, Buvanendran A, McCarthy RJ, Hemmati H, Tuman KJ (2002) Cyclooxygenase-2 inhibition potentiates morphine antinociception at the spinal level in a postoperative pain model. Reg Anesth Pain Med 27:451-455

Kroin JS, Ling ZD, Buvanendran A, Tuman KJ (2004) Upregulation of spinal cyclooxygenase-2 in rats after surgical incision. Anesthesiology 100:364-369

Lipsky LP, Abramson SB, Crofford L, Dubois RN, Simon LS, van de Putte LB (1998) The classification of cyclooxygenase inhibitors. J Rheumatol 25:2298-2303

Nithipatikom K, Laabs ND, Isbell MA, Campbell WB (2003) Liquid chromatographic-mass spectrometric determination of cyclooxygenase metabolites of arachidonic acid in cultured cells. J Chromatogr B Analyt Technol Biomed Life Sci 785:135-145

Panara MR, Padovano R, Sciulli MG, Santini G, Renda G, Rotondo MT, Pace A, Patrono C, Patrignani P (1998) Effects of nimesulide on constitutive and inducible prostanoid biosynthesis in human beings. Clin Pharmacol Ther 63:672-681

Patrignani P, Panara MR, Greco A, Fusco O, Natoli C, Iacobelli S, Cipollone F, Ganci A, Creminon C, Maclouf J (1994) Biochemical and pharmacological characterization of the cyclooxygenase activity of human blood prostaglandin endoperoxide synthases. J Pharmacol Exp Ther 271:1705-1712

Rasmussen GL, Malmstrom K, Bourne MH, Jove M, Rhondeau SM, Kotey P, Ang J, Aversano M, Reicin AS (2005) Etoricoxib provides analgesic efficacy to patients after knee or hip replacement surgery: a randomized, double-blind, placebocontrolled study. Anesth Analg 101:1104-1111, table

Reinold H, Ahmadi S, Depner UB, Layh B, Heindl C, Hamza M, Pahl A, Brune K, Narumiya S, Muller U, Zeilhofer HU (2005) Spinal 
inflammatory hyperalgesia is mediated by prostaglandin $\mathrm{E}$ receptors of the EP2 subtype. J Clin Invest 115:673-679

Riendeau D, Percival MD, Brideau C, Charleson S, Dube D, Ethier D, Falgueyret JP, Friesen RW, Gordon R, Greig G, Guay J, Mancini J, Ouellet M, Wong E, Xu L, Boyce S, Visco D, Girard Y, Prasit P, Zamboni R, Rodger IW, Gresser M, Ford-Hutchinson AW, Young RN, Chan CC (2001) Etoricoxib (MK-0663): preclinical profile and comparison with other agents that selectively inhibit cyclooxygenase-2. J Pharmacol Exp Ther 296:558-566

Samad TA, Moore KA, Sapirstein A, Billet S, Allchorne A, Poole S, Bonventre JV, Woolf CJ (2001) Interleukin-1beta-mediated induction of Cox-2 in the CNS contributes to inflammatory pain hypersensitivity. Nature 410:471-475

Samad TA, Sapirstein A, Woolf CJ (2002) Prostanoids and pain: unraveling mechanisms and revealing therapeutic targets. Trends Mol Med 8:390-396

Schmidt R, Coste O, Geisslinger G (2005) LC-MS/MS-analysis of prostaglandin E2 and D2 in microdialysis samples of rats. J Chromatogr B Analyt Technol Biomed Life Sci 826:188-197

Schwartz JI, Dallob AL, Larson PJ, Laterza OF, Miller J, Royalty J, Snyder KM, Chappell DL, Hilliard DA, Flynn ME, Cavanaugh PF Jr, Wagner JA (2008) Comparative inhibitory activity of etoricoxib, celecoxib, and diclofenac on COX-2 versus COX-1 in healthy subjects. J Clin Pharmacol 48:745-754

Shen DD, Artru AA, Adkison KK (2004) Principles and applicability of CSF sampling for the assessment of CNS drug delivery and pharmacodynamics. Adv Drug Deliv Rev 56:1825-1857

Smirnov G, Terava M, Tuomilehto H, Hujala K, Seppanen M, Kokki H (2008) Etoricoxib for pain management during thyroid surgery - a prospective, placebo-controlled study. Otolaryngol Head Neck Surg 138:92-97

Sodemann B, Persson PE, Nilsson OS (1990) Nonsteroid antiinflammatory drugs prevent the recurrence of heterotopic ossification after excision. Arch Orthop Trauma Surg 109:53-56
Summerfield SG, Stevens AJ, Cutler L, del Carmen OM, Hammond B, Tang SP, Hersey A, Spalding DJ, Jeffrey P (2006) Improving the in vitro prediction of in vivo central nervous system penetration: integrating permeability, P-glycoprotein efflux, and free fractions in blood and brain. J Pharmacol Exp Ther 316:1282-1290

Tacconelli S, Capone ML, Sciulli MG, Ricciotti E, Patrignani P (2002) The biochemical selectivity of novel COX-2 inhibitors in whole blood assays of COX-isozyme activity. Curr Med Res Opin 18:503-511

Toivonen J, Pitko VM, Rosenberg PH (2007) Etoricoxib premedication combined with intra-operative subacromial block for pain after arthroscopic acromioplasty. Acta Anaesthesiol Scand 51:316-321

Turan I, Hein A, Jacobson E, Jakobsson JG (2008) Sevoflurane requirement during elective ankle day surgery: the effects of etirocoxib premedication, a prospective randomised study. J Orthop Surg 3:40

US Department of Health and Human Services, FDA. Guidance for Industry: Bioanalytical Method Validation (2001) Rockville, CDER. Report, Ref Type

Ushiyama S, Yamada T, Murakami Y, Kumakura S, Inoue S, Suzuki K, Nakao A, Kawara A, Kimura T (2008) Preclinical pharmacology profile of CS-706, a novel cyclooxygenase-2 selective inhibitor, with potent antinociceptive and anti-inflammatory effects. Eur J Pharmacol 578:76-86

Viola M, Quaratino D, Gaeta F, Caruso C, Valluzzi R, Romano A (2007) Etoricoxib tolerability in patients with hypersensitivity to nonsteroidal anti-inflammatory drugs. Int Arch Allergy Immunol 143:103-108

Wilkinson GR (1983) Plasma and tissue binding considerations in drug disposition. Drug Metab Rev 14:427-465

Woolf CJ, Chong MS (1993) Preemptive analgesia - treating postoperative pain by preventing the establishment of central sensitization. Anesth Analg 77:362-379 